\title{
Семья как фактор социальных девиаций личности
}

Семья является важнейшим институтом социализации личности. Именно в семье человек получает первый опыт социального взаимодействия. На протяжении какого-то времени семья вообще является для ребенка единственным местом получения такого опыта. Затем в жизнь человека включаются такие социальные институты как детский сад, школа, улица. Однако и в это время семья остается одним из важнейших, а иногда и наиболее важным, фактором социализации личности. Семью можно рассматривать в качестве модели и формы базового жизненного тренинга личности. Социализация в семье происходит как в результате целенаправленного процесса воспитания, так и по механизму социального научения. В свою очередь сам процесс социального научния также идет по двум основным направлениям. С одной стороны, приобретение социального опыта идет в процессе непосредственного взаимодействия ребенка с родителями, братьями и сестрами, а с другой стороны, социализация осуществляется за счет наблюдения особенностей социального взаимодействия других членов семьи между собой.

Традиционно принято говорить о семье как факторе защиты развивающейся личности. Мы же хотели бы акцентировать внимание на возможных деструктивных влияниях семьи на развитие личности и рассмотреть семью как фактор риска социально девиантного поведения и развития личности. К семьям с психосоциальными нарушениями следует относить семьи с проблемами алкоголизации и наркомании, асоциальными ценностями, противоправным поведением, с высоким уровнем конфликтности, семьи, практикующие агрессивное поведение и насилие над ребенком, семьи с эмоциональной депривацией ребенка. Многие семейные нарушения коррелируют с делинквентным поведением подростков, что подтверждается данными статистики и специальных исследований.

Долгое время считалось, что социально девиантное развитие личности связано со структурной деформаций семьи, под которой понимается просто неполная семья - отсутствие одного из родителей (чаще отца). Статистические данные по преступности несовершеннолетних, полученные в разных странах мира, подтверждали этот вывод. Однако в 60 - 70-е годы обнаружилась другая тенденция. Сначала разница между полными и неполными семьями по количеству «выдаваемых» ими подростков-делинквентов стала неуклонно сокращаться, а затем и практически полностью исчезла. В настоящее время считается, что основным фактором негативного влияния семьи на развитие личности является не структурная, а психосоциальная деформация семьи. И это общемировая тенденция. 


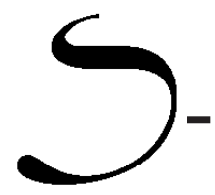

Вместе с тем, следует подчеркнуть, что структурная деформация семьи все-таки крайне нежелательна. Она вносит значительный вклад в развитие социальных девиаций личности, особенно если круг этих девиаций не сводить только кделинквентному поведению. Да и по вкладу в делинквентность данные различных исследований всетаки достаточно противоречивы. Так, по данным одного из российских исследований, в структурно деформированной (то есть, неполной) семье проживает около 50\% подростков-делинквентов. А, значит, вторая половина имеет полную семью. А вот проблемы с различными проявлениями психосоциальной деформации семьи оказываются характерными для более $70 \%$ процентов подростков-правонарушителей (Королев В.В.). По данным другого исследования (Забрянский Г.И.), фиксируется в принципе та же тенденция, хотя сами цифры заметно отличаются: в неполной семье воспитывалось 39\% осужденных несовершеннолетних, а в полной - 56\% . Правда, здесь надо учитывать, что само количество неполных и полных семей в обществе неодинаково - первых все-таки меньше. Имеются и такие данные, которые и вовсе не укладываются в выше означенную тенденцию. Так, по данным одного из исследований осужденных несовершеннолетних (Ильяшенко А.Н.), 53\% юношей-преступников и 62\% девушек-преступниц проживали в неполной семье (распавшейся или не созданной). В контрольной же группе правопослушных несовершеннолетних таких подростков оказалось соответственно в 2 и в 2,5 раза меньше.

В целом же, когда мы говорим о разном вкладе в развитие асоциальности несовершеннолетних психосоциальной деформации и собственно структурной деформации семьи, надо отдавать себе отчет в том, что это не изолированно полярные категории. Психосоциальная деформация понятие более широкое, чем структурная деформация. Ведь психосоциальная деформация может быть присуща как полной, так и не полной семье. Хотя, скорее всего, в статистическом плане и не в равной мере.

Важнейшим механизмом негативного влияния семьи на развитие личности как раз и является социализация в семье по девиантному типу. Асоциальные ценности, нормы и стереотипы поведения могут усваиваться по механизму научения и подражания, если именно такие ценности и нормы являются доминирующими в данной семье. В соответствии с концепцией социального научения (Bandura A.), процесс социализации состоит в развитии привычных ответных реакций, принятых в обществе, в котором индивид живет. В рамках данной концепции асоциальное поведение рассматривают как результат специфичного социального научения. При этом считается, что основания развития и закрепления такого поведения следует в первую очередь искать в том, как родители воспитывали своих детей в первые годы жизни, а также и в более поздние периоды, включая и собственно подростковый возраст. При этом закрепление социально девиантного развития может идти тремя путями: за счет прямого декларирования асоциальных ценностей и норм, и подчеркивания «что только так и можно достичь успеха»; за счет проявления девиантного, асоциального поведения при непосредственном взаимодействии родителей с ребенком; за счет наблюдения ребенком в реальном поведении 
родителей социально девиантной направленности, даже если на вербальном уровне ими декларируется приверженность просоциальному поведению и просоциальной шкале ценностей.

Формирование просоциального поведения личности связано не только с механизмами отсутствия подкрепления или активного наказания за асоциальное поведение, но и обязательно (и, может быть, даже в первую очередь) с активным социальным научением просоциальным формам поведения, конструктивным способам разрешения противоречий и реализации различных мотиваций личности. Ведь как установлено, наиболее выраженные различия между детьми с деструктивным и конструктивным социальным поведением обнаруживаются не в личностном предпочтении деструктивных альтернатив, а в незнании конструктивных решений. Таким образом, процесс социализации конструктивного поведения включает приобретение системы знаний и социальных навыков, а также воспитание системы личностных диспозиций, установок, на основе которых формируется способность реагировать на фрустрацию относительно приемлемым образом.

В семье подросток усваивает поведенческие паттерны разрешения жизненных ситуаций и определенные ценностные представления. Семья с алкогольными проблемами, например, повышает вероятность декомпенсации поведения у подростков и обусловливает социально-педагогическую запущенность, развитие инфантильных черт личности, невротические расстройства. Но вместе с тем она делает привычным сам стиль семейных отношений, формирующих незрелую личность, прибегающую в сложных ситуациях к суррогату межличностного взаимодействия - алкоголю, наркотику (Емельянцева Т.А.).

Другим важным механизмом влияния семьи на развитие социальных девиаций и асоциального поведения личности является эмоциональное пренебрежение ребенком, «неценностное» отношение к нему. Существует огромное число исследований, которые убедительно показывают зависимость между негативными взаимоотношениями в системе «родители-ребенок», эмоциональной депривацией в семье и социально девиантным развитием личности. Установлено, например, что если у ребенка сложились негативные отношения с одним или обоими родителями, если тенденции развития позитивности самооценки и Я-концепции не находят поддержки в оценках родителей или если ребенок не ощущает родительской поддержки и опеки, то вероятность делинквентного, противоправного поведения существенно возрастает, ухудшаются отношения со сверстниками, проявляется агрессивность по отношению к собственным родителям.

Важнейшим условием эффективной социализации и предупреждения становления девиантных форм поведения является развитие мотивации привязанности, посредством которой у ребенка появляется необходимость в интересе, внимании и одобрении окружающих, и в первую очередь - собственных родителей. В качестве вторичного подкрепления привязанность затем может обусловливать приспособление ребенка к социальным требованиям и запретам, то есть к просоциальному поведению. В этой связи следует подчеркнуть, что важным условием развития социально 
девиантного поведения является не только социальное научение как таковое, но и фрустрация, возникающая при отсутствии родительской любви и при постоянном применении наказаний со стороны либо одного, либо обоих родителей.

Исследования показывают, например, что агрессивные и неагрессивные подростки имеют различную степень привязанности к родителям и близости с ними. Предметом одного такого исследования (Bandura A., Walters R.) было изучение особенностей идентификации с родителями агрессивных и неагрессивных мальчиков-подростков. В целом было установлено, что у неагрессивных подростков идентификация с собственными родителями выражена сильнее, чем у агрессивных. Однако степень различия между этими двумя группами подростков по идентификации с матерью и отцом оказалась неодинаковой. Наиболее сильные различия между агрессивными и неагрессивными подростками обнаруживаются по степени идентификации с отцом. Соответствующие различия по степени идентификации с матерью оказались менее выраженными. То есть идентификация с матерью, как у неагрессивных, так и у агрессивных подростков оказалась высокой и достаточно близкой по среднегрупповому показателю.

Последний факт, по нашему мнению, может быть проинтерпретирован как еще одно проявление особого значения матери в системе привязанностей и социальных отношений подростка. Очевидно, нарушения идентификации с матерью могут быть обнаружены не при любых, а только при очень серьезных нарушениях развития личности. Так, в одном исследовании (Реан А. А., Санникова М. Ю.) было показано, что в системе отношений подростка к социальному окружению (в том числе определялось и отношение к отцу, а также к сверстникам) именно отношение к матери оказалось наиболее положительным. Было установлено, что снижение положительного отношения к матери, увеличение негативных дескрипторов (характеристик) при описании матери коррелирует с общим ростом негативизации всех социальных отношений личности. Можно полагать, что за этим фактом стоит фундаментальный феномен проявления тотального негативизма (негативизма ко всем социальным объектам, явлениям и нормам) у тех личностей, для которых характерно негативное отношение к собственной матери. В целом, как установлено в исследовании, негативное отношение к собственной матери является важным показателем общего неблагополучного развития личности.

Возвращаясь к названию этой статьи, хочется заметить, что семья не должна быть фактором социальных девиаций личности, то есть, в конечном счете, фактором социальной дезадаптации. Это противоестественно. Семья, напротив, должна быть и оставаться фактором эффективной социализации личности, то есть, в конечном счете, важнейшим фактором социальной адаптации и успешности личности. Но достижение этой цели, как оказалось, требует усилий. Усилий конкретных личностей, микросоциума, всего общества и, обязательно, усилий государства. Усилия эти должны быть направлены на всемерное укрепление семейных ценностей в обществе, на комплексную поддержку семьи и социальную заботу о ее развитии. 